\title{
Exogenous folates stimulate growth and budding of Candida glabrata
}

\author{
Afsaneh Porzoor and lan G. Macreadie* \\ School of Applied Sciences, RMIT University, Bundoora, Victoria 3083, Australia. \\ * Corresponding Author: Prof. Ian Macreadie, RMIT University, Bundoora; Victoria 3083, Australia; Tel: +61 399256627 ; Fax: +61 3 \\ 9925 7110; E-mail: ian.macreadie@rmit.edu.au
}

\begin{abstract}
Folate, vitamin B9, is well recognized as being essential for cell growth. The utilization of folate is common to all cells, but the source of it may be quite different. For example, mammalian cells depend on exogenous uptake of folates, while plants and microbes can synthesize them. There has been little consideration of uptake of folate in microbial cells, and studies on the effects of folates in mammalian cells, where conditions are restricted. This study shows that exogenous folates (folic acid or folinic acid), causes Candida glabrata cells suspended in water alone to undergo two cycles of cell division and to form multiple buds. The effect was limited to cells in the stationary phase and more profound in quiescent cells. These data indicate a novel response of yeast to folates that may increase the utility of yeast as a model to study folate transport and signaling.
\end{abstract}

doi: 10.15698/mic2015.05.202 Received originally: 03.05.2014, in revised form: 07.04.2015,

Accepted 24.04.2015,

Published 01.05.2015.

Keywords: Candida glabrata, folate, proliferation, quiescence, unscheduled cell division.

\section{INTRODUCTION}

Folates are essential for all life. Also known as a family of pteroylglutamates (which includes folate - folic acid - vitamin B9), folates are necessary for one carbon metabolism, and for facilitating the production of proteins and DNA. Mammalian cells cannot synthesize folates and are dependent on folates in their diet, utilising receptors and transporters to deliver them into cells. Plants and microbes synthesise folates de novo and therefore should have no need for the uptake of folates and for folate transporters and receptors. Yeast with folate synthesis genes deleted, demonstrate that folate, or the cellular processes depending on it are essential $[1,2]$. These yeast deletion strains can be grown in media containing folinic acid or folic acid, or through the addition of adenine, methionine, histidine and thymidine monophosphate, using a TUP1 strain that contains a thymidine uptake mutation.

Information on uptake of folates comes from a variety of mammalian cell studies, including naturally occurring human mutations that inform us about the importance of uptake of folates for proper embryonic development, and prevention and treatment of disease throughout life, including age-related diseases like Alzheimer's disease. Microbial models have been important in providing fundamental information about human health and disease, yet insights into uptake of folates have not occurred in microbial models due to an assumption that they would be irrel- evant, since they do not rely on exogenous folates. In this study we have focused on the effects of exogenous folates on yeast, since yeast can be extensively manipulated in terms of its environment and genes. For example, yeast can be maintained for long periods in a quiescent state, simply by holding them in aqueous suspension. Our work in this study focused on the effects of added folates on yeast suspended in water.

\section{RESULTS}

Folates induce cells in stationary phase to proliferate and bud

C. glabrata cells were grown to stationary phase, and then suspended in water with folic or folinic acid in concentrations up to $1 \mathrm{mM}$. The addition of folic and folinic acid caused a significant increase in the viability within the first $24 \mathrm{~h}$ measured by CFUs (colony forming units) (Fig. $1 \mathrm{~A}, \mathrm{~B}$ ). Treatments with 10 and $100 \mu \mathrm{M}$ folic acid (Fig. 1A) or 100 and $1000 \mu \mathrm{M}$ folinic acid (Fig. 1B) led to significant increases in CFUs. Our studies have focused on the lower concentrations that caused an increase in CFUs. The effect on cell proliferation caused by folates was limited to the cells in stationary phase and no effect was detected on cells growing in exponential phase (data not shown).

The cells were fractionated in quiescent and nonquiescent populations on a Percoll gradient for further examination. Induction of cell proliferation by folates was 
A

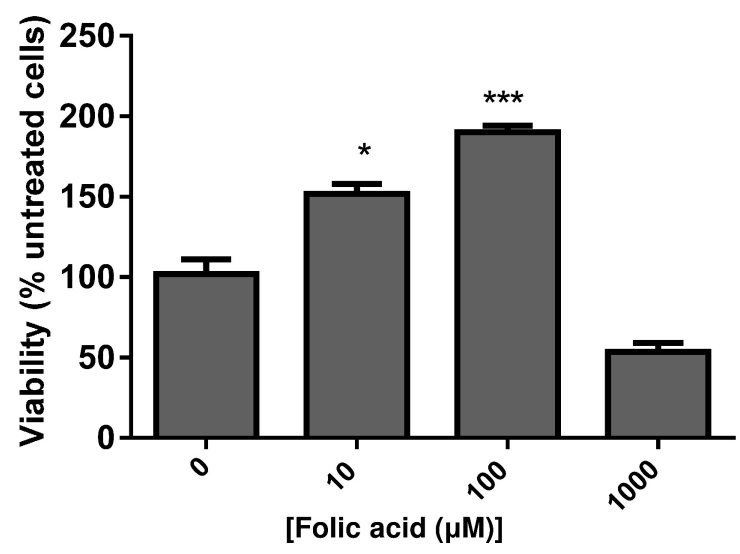

C

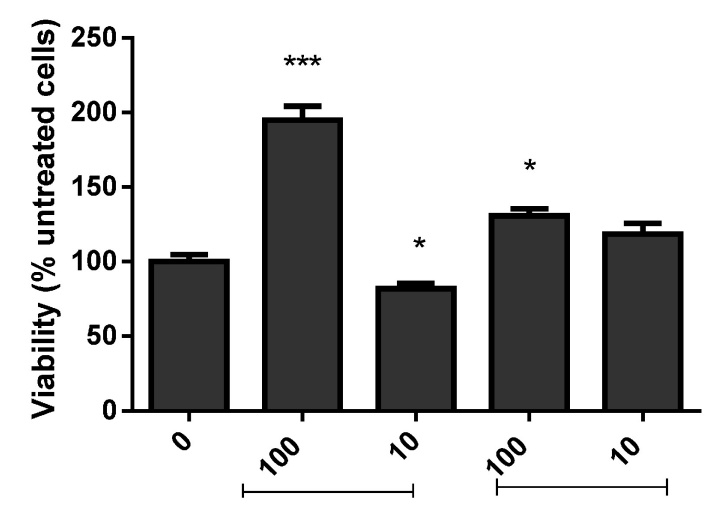

[Folic acid $(\mu \mathrm{M})]$ [Folinic acid $(\mu \mathrm{M})]$
B

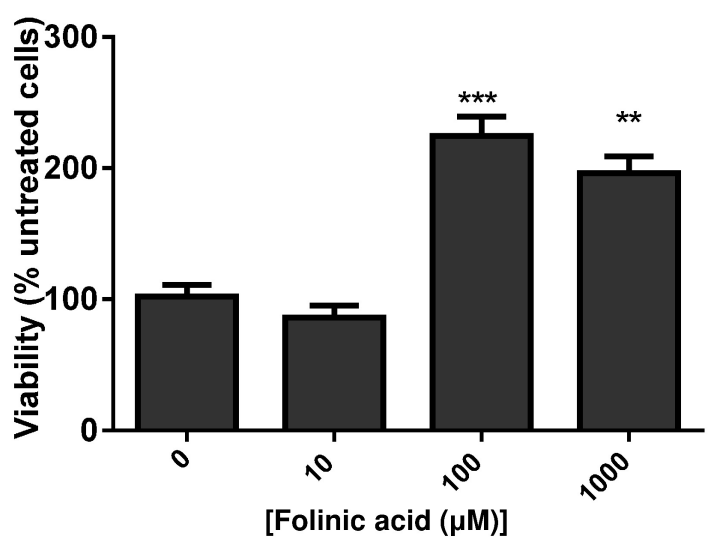

D

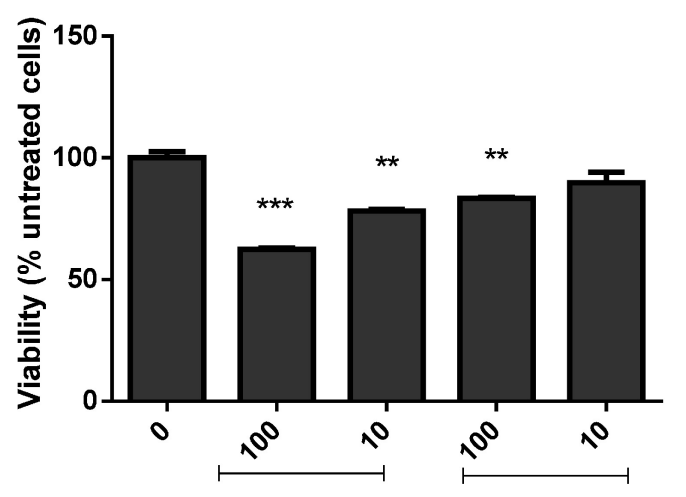

[Folic acid $(\mu \mathrm{M})] \quad[$ Folinic acid $(\mu \mathrm{M})]$

FIGURE 1: Effect of folic acid (A) and folinic acid (B) on the survival of stationary phase yeast. Cells $\left(10^{3}\right.$ cells $\left./ \mathrm{ml}\right)$ were incubated overnight at $30^{\circ} \mathrm{C}$ with shaking at $200 \mathrm{rpm}$. Viability was estimated by determination of CFUs. The viability of quiescent (C) and non-quiescent (D) fractions of stationary phase yeast in the presence of $10 \mu \mathrm{M}$ and $100 \mu \mathrm{M}$ of folic acid and folinic acid was compared with the control. ( ${ }^{*} \mathrm{P}<$ $0.05, * * P<0.01, * * * P<0.005)$. All data are shown as mean $+/-$ SEM.

limited to quiescent cells with a significant increase in the number of cells in the presence of $100 \mu \mathrm{M}$ of folic acid ( $P<$ 0.01 ) and folinic acid $(P<0.05)$. A non-quiescent subfraction of cells did not behave similarly: folates seemed to reduce their viability (Fig. 1 C,D).

Stationary phase cultures were also examined microscopically after folic and folinic acid treatments for a period of $10 \mathrm{~d}$. Prior to treatment, the population consisted of over $90 \%$ unbudded cells and approximately $10 \%$ budded cells. After $24 \mathrm{~h}$ incubation in water, most cells grew at least one bud, while cells treated with folate budded synchronously and had the ability to form multiple buds (Fig. $2 \mathrm{~A})$. Some cells grew three or four buds, while no folate addition resulted in no increase in budding. After prolonged incubation in water these yeast cells became larger and more transparent, causing difficulties with cell imaging. Interestingly, both axial and bipolar forms of budding were viewed after the treatment. Although some cells in the control samples had more than one bud, the total percent- age was much lower than those of the treated samples. In particular, it appears that the response operates in a dosedependent manner: as the concentration of folate increases, more multi-budded cells can be counted compared with lower concentrations. This effect persists and could be viewed for the ten day period in which the cells were monitored (Fig. 2A). Cells also seemed more adherent and became larger and more elongated as the incubation continued.

\section{Flow cytometry analysis of treated cells}

Cell growth in the folate treated cells was also examined by calcofluor white staining of bud scars. In the presence of folic and folinic acid there were dose-dependent increases in the fluorescence intensity (Fig. 2B). The fluorescence intensity increased by $41.4 \%(P<0.005), 24.8 \%(P<0.01)$ and $19.0 \%(P<0.05)$ in samples treated with 1000,100 and $10 \mu \mathrm{M}$ of folic acid, respectively, compared with the control where $15.6 \%$ of cells exhibited fluorescence from 
calcofluor (Fig. 2B). Folinic acid also increased the fluorescence intensity of the cells but to a lesser extent: values of $26.8 \%, 21.0 \%$ and $19.0 \%$ were obtained respectively (Fig. 2 B). These results support our observations from both plate counts and microscopy which showed an increase in the number of cells and particularly the number of multibudded cells.

Flow cytometry of cells after calcofluor staining showed three distinct populations of $C$. glabrata cells (Fig. 2C). The least stained cells are newly budded cells, and the more highly stained cells have one or more bud scars. It can be seen that treatment with folic or folinic acid led to an increased proportion of the populations with one or more bud scars.

\section{DISCUSSION}

In the present study we investigated the influence of folates on yeast cells in the absence of nutrients. The exogenous addition of folic and folinic acid induced cell proliferation, suggesting an effect of folates on the cell cycle, possi- bly through a cell surface receptor, that would signal cell division processes to commence. Granot and Snyder [3] showed that glucose could induce $S$. cerevisiae suspended in water to enter the cell cycle, however, this was associated with a loss of viability. The effect of folates in this study led to an increase in cell number, except for the addition of a very high level folic acid $(1000 \mu \mathrm{M})$ which led to a loss of viability: however, survivors from that treatment grew into larger colonies. The differences in such effects are currently unclear, but we speculate that they may relate to the level of signaling. For example, sustained signaling to divide in the absence of nutrition would presumably lead to cell death. We presume that this happens in water with both glucose, and with $1000 \mu \mathrm{M}$ folic acid.

The budding pattern induced by folates was also notable. C. glabrata normally exhibits only axial budding pattern but folates induced both axial and bipolar forms of budding. It is known that yeast actin cytoskeleton is responsible for polarized growth during budding in the course of the cell cycle [4]. Although, in haploid cells the absence of sugar have been reported to cause bud switch-

FIGURE 2: Effect of folates on yeast budding. (A) Light microscopy images of $C$. glabrata in the presence of $100 \mu \mathrm{M}$ folic acid and folinic acid compared to the control for up to 10 days. (Scale bar $=10 \mu \mathrm{m}$ ). Calcofluor staining of the bud scars in stationary phase yeast incubated in the presence of 1000, 100 and $10 \mu \mathrm{M}$ folic acid and folinic acid, analysed by flow cytometry. (B) Histograms represent the results from three independent experiments. ( $\left.{ }^{* *} \mathrm{P}<0.005,{ }^{* *} \mathrm{P}<0.01,{ }^{*} \mathrm{P}<0.05\right)$. (C) Flow cytometry profile of cell populations in the presence of $1 \mathrm{mM}$ folic and folinic acid. 
ing from axial to a unipolar-distal budding pattern, no study (to our knowledge) has shown the appearance of three to four buds on cells deprived of nutrients while in stationary phase.

Cells in stationary phase are well equipped for survival and have some reserves for growth. This is clearly demonstrated by our observations that such cells can double without need for additional exogenous nutrients. Also previous studies on $S$. cerevisiae have shown the level of intracellular carbohydrate increases during stationary phase but this increase in intracellular storage does not correlate with long term viability of the cells $[5,6]$. The effect of folate appears limited to stationary phase culture further confirming that regulation of gene expression in yeast is different during the stationary phase of the growth cycle compared to the exponential phase. Further questions relate to why folates have this effect, since it seems counterintuitive that yeast, an organism that normally synthesizes its own folate, should respond to exogenous folic or folinic acid.

Additionally we have shown proliferation in the quiescent cells whereas the non-quiescent cells lost their viability in the presence of folate. This result is in agreement with previous work demonstrating the presence of a mature spindle pole body and low ROS in quiescent cells versus a premature spindle pole body and higher level of ROS in non-quiescent cells, making the latter more susceptible to environmental changes [6-8].

\section{MATERIALS AND METHODS}

Yeast strain, media and storage condition

C. glabrata ATCC90030 was utilised in this study. Chemicals, solvents and reagents were purchased from Sigma-Aldrich ${ }^{\circledR}$ (Australia) unless otherwise stated. All cells were grown in YEPD (1\% yeast extract, $2 \%$ peptone and $2 \%$ D-glucose) with aeration at $30^{\circ} \mathrm{C}$. For short-term storage ( $<3$ weeks), yeast cells were maintained on YEPD solidified media at $4^{\circ} \mathrm{C}$. For long-term storage, yeast cells were stored $-80^{\circ} \mathrm{C}$ in YEPD or suitable selective broth and $15 \%$ glycerol.

\section{Stationary and exponential phase growth of yeast}

In order to prepare yeast for stationary phase analysis, cells were grown in YEPD broth with aeration at $30^{\circ} \mathrm{C}$ for 7 days with shaking $(200 \mathrm{rpm})$. Cells were then pelleted and washed twice and resuspended in filter sterilized $\mathrm{H}_{2} \mathrm{O}$ at the density of $10^{5}$ cells $/ \mathrm{ml}$ for further treatment. For yeast in exponential growth phase, yeast cells were grown overnight in YEPD broth and then $1 \mathrm{ml}$ was inoculated into $80 \mathrm{ml}$ of fresh media and incubated at $30^{\circ} \mathrm{C}$ with shaking $(200 \mathrm{rpm})$ for $2-3 \mathrm{~h}$ to reach an $\mathrm{OD}_{600}$ of 1.0 .

\section{Fractionation of yeast cells into quiescent and non-quiescent populations}

Percoll density gradients (GE Healthcare) were prepared according to the manufacturer's protocol and the method described by Allen and colleagues [9] with some modification. Briefly, to form a gradient, $9 \mathrm{ml}$ of Percoll was mixed with one $\mathrm{ml}$ of $1.5 \mathrm{M} \mathrm{NaCl}$. This solution was then added to $15 \mathrm{ml}$ Corex tubes and centrifuged at $13,800 \mathrm{rpm}$ for $15 \mathrm{~min}$ at $20^{\circ} \mathrm{C}$ in Beckman Coulter centrifuge (SW41Ti rotor). $\sim 2 \times 10^{9}$ station- ary phase yeast cells, which were grown for 7 days at $30^{\circ} \mathrm{C}$ (200 rpm), were pelleted and resuspended in $1 \mathrm{ml}$ Tris buffer $(50 \mathrm{mM}, \mathrm{pH}$ 7.5). Around $2 \mathrm{ml}$ of cell suspension was overlaid onto the preformed gradient, and centrifuged at $400 \mathrm{~g}$ for 60 min in a Beckman Coulter centrifuge (Avanti J25-01). Fractions of quiescent and non-quiescent were collected and washed three times in $40 \mathrm{ml}$ Tris buffer and then resuspended in $\mathrm{ddH}_{2} \mathrm{O}$ for analysis.

\section{Folic acid and folinic acid treatment of $C$. glabrata}

$10 \mathrm{mM}$ stock solutions of folic acid and folinic acid were made in water. Folic acid was dissolved with addition of $\mathrm{NaOH}$ and $\mathrm{pH}$ was adjusted to 7.0 prior to use. All solutions, including the folate stock solutions, were filter sterilized through $0.22 \mu \mathrm{m}$ syringe filters (Sarstedt). Stationary phase C. glabrata were washed and suspended in sterile water to densities of $10^{5}$ cells $/ \mathrm{ml}$ for microscopy and flow cytometry, or $10^{3}$ cells $/ \mathrm{ml}$ for CFU analyses. For folic acid and folinic acid treatments, the yeast cells were transferred into 96-well culture plates and 10fold dilutions series of the folates were made to achieve concentrations of $1 \mathrm{mM}$ and lower. Samples in triplicate were treated with $10-1000 \mu \mathrm{M}$ of folic acid or folinic acid and incubated for a period of up to 10 days. Aliquots were taken every $24 \mathrm{~h}$ for microscopy and CFU determination.

\section{Cell viability assay}

Cell viability was determined by plating $100 \mu$ l aliquots of cell suspension from both treated and untreated samples on YEPD plates and counting the number of colonies produced after at least 2 days of incubation at $30^{\circ} \mathrm{C}$. Colonies were counted and the data presented as a percentage of untreated samples.

\section{Calcofluor staining of bud scars}

Working solutions of $25 \mu \mathrm{M}$ calcofluor white M2R were prepared from a $5 \mathrm{mM}$ stock solution. Folic acid and folinic acid treated stationary phase $C$. glabrata cells $\left(2 \times 10^{5}\right.$ cells $\left./ \mathrm{ml}\right)$ were stained with this working solution and incubated for 10 $\mathrm{min}$ in the dark at room temperature. Around 30,000 cells per sample were analysed by flow cytometry (FACS, Canto II- BD ${ }^{\mathrm{TM}}$ ) using $351 \mathrm{~nm}$ excitation and collecting fluorescence emission with filters at 450/65. Data were recorded and saved as FCS3 files. All data were analysed by WEASEL (WEHI, Parkville, Australia) software.

\section{Microscopic analysis of cell morphology}

Around $10 \mu \mathrm{l}$ of each sample was taken and using a wet mount method, loaded on a microscopic slide for imaging using oil immersion on an Olympus CX31 light microscope. Images were captured using an Olympus digital camera (E330- Japan).

\section{Statistical analyses}

Prism 5 for windows version 5.04 (GraphPad software, Inc., La Jolla, CA, USA) was used to perform statistical analyses. All data are presented as mean with a standard error of the mean, and differences were compared using unpaired Student's $t$ test and one way ANOVA with Tukey post hoc test. Significant differences are indicated by asterisks: ${ }^{*} \mathrm{P}<0.05$; ${ }^{* * P}<0.01$; $* * * \mathrm{P}<0.005$.

\section{ACKNOWLEDGMENTS}

This work is supported in part by a grant from the Medical Advances Without Animals Trust (MAWA). 


\section{CONFLICT OF INTEREST}

The authors declare no conflict of interest.

\section{COPYRIGHT}

(C) 2015 Porzoor and Macreadie. This is an open-access article released under the terms of the Creative Commons Attribution (CC BY) license, which allows the unrestricted use, distribution, and reproduction in any medium, provided the original author and source are acknowledged.

\section{REFERENCES}

1. Bayly AM, Macreadie IG (2002). Cytotoxicity of dihydropteroate in Saccharomyces cerevisiae. FEMS Microbiol Letts 213(2): 189-192.

2. Swarbrick JD, Iliades P, Simpson JS, Macreadie I (2008). Folate biosynthesis- Reappraisal of old and novel targets in the search for new antimicrobials. Open Enzym Inhib J 1:12-33.

3. Granot D, Snyder M (1993). Carbon source induces growth of stationary phase yeast cells, independent of carbon source metabolism. Yeast 9(5): 465-479.

4. Pruyne D, Bretscher A (2000). Polarization of cell growth in yeast. I. Establishment and maintenance of polarity states. J Cell Science 113 ( Pt 3), 365-375.

5. Slaughter JC, Nomura T (1992). Intracellular glycogen and trehalose contents as predictors of yeast viability. Enzyme and Microbial Technol 14(1): 64-67.
Please cite this article as: Afsaneh Porzoor and Ian G. Macreadie (2015). Exogenous folates stimulate growth and budding of Candida glabrata. Microbial Cell 2(5): 163-167. doi: 10.15698/mic2015.05.202

6. Werner-Washburne M, Braun E, Johnston GC, Singer RA (1993). Stationary phase in the yeast Saccharomyces cerevisiae. Microbiol Rev 57(2): 383-401.

7. Gray JV, Petsko GA, Johnston GC, Ringe D, Singer RA, WernerWashburne M (2004). "Sleeping beauty": quiescence in Saccharomyces cerevisiae. Microbiol Mol Biol Rev 68(2): 187-206.

8. Aragon AD, Rodriguez AL, Meirelles O, Roy S, Davidson GS, Tapia $\mathrm{PH}$, Allen C, Joe R, Benn D, Werner-Washburne M (2008). Characterization of differentiated quiescent and nonquiescent cells in yeast stationary-phase cultures. Mol Biol Cell 19(3): 1271-1280.

9. Allen C, Buttner S, Aragon AD, Thomas JA, Meirelles O, Jaetao JE, Benn D, Ruby SW, Veenhuis $M$, Madeo F, Werner-Washburne $M$ (2006). Isolation of quiescent and nonquiescent cells from yeast stationary-phase cultures. J Cell Biol 174(1): 89-100. 